\title{
DECENTRALIZATION AND RE-CENTRALIZATION OF ELECTRICITY INDUSTRY GOVERNANCE IN NEW ZEALAND
}

\author{
PAPER FOR CONFERENCE \\ "THE EUROPEAN ELECTRICITY MARKET" \\ SEPTEMBER 20-22, 2004, LODZ, POLAND
}

\author{
Richard MEADE \\ New Zealand Institute for the Study of Competition and Regulation Inc \\ Cognitus Advisory Services Limited (New Zealand)
}

\begin{abstract}
For much of the twentieth century electricity generation and transmission in New Zealand was dominated by centralized state ownership and control, with local authority ownership of distribution and retailing. Radical reform of the sector commenced in the early 1980s, with the progressive corporatisation and unbundling of these sub-sectors, limited privatizations, and a shift towards "light-handed" non-industry specific regulation. These reforms contained inherent tensions that quickly manifested themselves in a political stand-off over the electricity price path required to support new generation investment. In turn this standoff spurred the industry-led development of a voluntary, self-governing wholesale electricity market. With a change of government in 1999 increasing re-centralization of industry governance and regulation resulted, in part justified on the grounds of winter power "crises" in 2001 and 2003 involving significant wholesale electricity price spikes (although blackouts were a regular and more disruptive occurrence prior to the reforms). With the return to centralized industry governance and shift towards heavyhanded regulation - but now with greater private sector investment in the sector - system supply and security issues persist, and questions remain over the likely effect of these policy reversals on required new investment.
\end{abstract}

Note: This paper draws on Evans, L. and Meade, R.: Contemporary Electricity Reform in
New Zealand, New Zealand Institute for the Study of Competition and Regulation Inc, www.iscr.org.nz, forthcoming.

\section{INTRODUCTION}

\subsection{Profile of New Zealand}

New Zealand is a South Pacific country comprising two main islands (South and North), with a population of around 4 million and a land area approximately $85 \%$ of that of Great Britain and Ireland combined. Its nearest neighbour, Australia, is some $2,500 \mathrm{~km}$ to the west. It is a stable liberal democracy, being a constitutional monarchy with a single legislative body and a member of the British Commonwealth. Since 1996 it has elected governments under a mixed member proportional representation (MMP) voting system, which replaced the previous first-past-the-post (FPP) system. The population is predominantly European in origin, with the indigenous Maori people comprising around $15 \%$ of the population.

\subsection{Reform context}

By 1984 the New Zealand economy was heavily protected, regulated and taxed. Major economic sectors, notably 
agriculture, were heavily subsidised, and government was involved in a wide range of commercial activities including electricity generation and transmission, financial services, telecommunications and transportation. Such taxpayer investments showed little financial return and also suffered poor levels of service delivery.

In 1984 a reform- and market-minded Labour government came to power and quickly embarked on a radical programme of economic restructuring and liberalization aimed at improving the nation's economic efficiency. Markets were deregulated, subsidies eliminated and tariffs phased out. State-owned trading enterprises - including electricity generation and transmission were corporatised and subjected to increased commercial disciplines while given greater operational autonomy, and in many cases were privatized. Industryspecific regulation was replaced by a common competition policy with "lighthanded" regulation backed by the threat of direct regulation where warranted. Statutory monopolies in a variety of sectors were removed. Many economic sectors, such as electricity retailing and distribution, were similarly subjected to significant changes after years of relative stability.

For much of the past 20 years the broad thrust of these reforms has been maintained, although less so with time, in part due to the 1996 shift from the FPP to MMP voting system. With the election of a coalition government dominated by a "third way" Labour party in late 1999, and again in 2002, there has increasingly been reversals of a number of the earlier reforms, notably in the governance and control of the electricity sector.

\subsection{Paper organization}

Section 2 profiles the current New Zealand electricity system. Section 3 provides further detail on the reform of the electricity sector, highlighting the history of changes in industry governance and control. Section 4 discusses more recent industry governance reform directions and their motivations. Section 5 identifies ongoing supply security and investment issues in the light of these recent reforms. Section 6 discusses and concludes.

\section{NEW ZEALAND ELECTRICITY SYSTEM}

While oil satisfies around half of all New Zealand's energy demand (almost all of which is transport-related), electricity accounts for a quarter of energy demand. Total electricity consumption was 33,000 GWh in 2002 , with $44 \%$ of that consumed by industry (one third of that by a single aluminium smelter), $35 \%$ by residential consumers, and the remaining $21 \%$ by commercial users.

Generation is predominantly hydrobased ( $61 \%$ of 2002 output), followed by gas (25\%), geothermal (7\%), and other sources such as co-generation and windturbines (7\%). Four generators - three of which are state-owned $(62 \%$ of total capacity) - meet $93 \%$ of electricity demand. Due to geographical isolation, no electricity can be imported or exported.

While $58 \%$ of the country's $8,305 \mathrm{MW}$ of 2002 generation capacity is in the North Island, the main hydro catchments are predominantly in the south of the South Island. Demand is concentrated in the North Island, particularly around the country's largest city, Auckland. This, combined with New Zealand's topography, means that the $17,500 \mathrm{~km}$ of national transmission grid is long, skinny and sparse, with the country's two main islands interconnected by a 1,040 MW, $575 \mathrm{~km}$ HVDC link, $40 \mathrm{~km}$ of which is submarine.

With hydro storage capacity being only $12 \%$ of annual demand, hydro inflows into the main catchments being volatile $(-30 \%)$ $+35 \%$ ), and winter-peaking demand, the system has long been vulnerable to winter supply shortages, most recently in 1992, 2001 and 2003. The supply situation is tightening further relative to ever-growing demand due to the run-down of the country's major gas field, Maui, and current lack of significant alternative gas sources.

Around $80 \%$ of wholesale electricity is traded through a centralized wholesale electricity market (WEM), with the balance traded bilaterally. Electricity is retailed via vertically integrated generator/retailers, while local distribution is undertaken by 28 electricity line businesses, most of which are community- or customer-trust owned. Residential and industrial electricity prices - despite significant price rebalancing 
since the reforms - remain at the lowest end of OECD comparisons. Since 1 March 2004 the electricity sector is governed by a newly-formed and government-controlled body, the Electricity Commission (EC).

Figure 1 depicts New Zealand's current electricity system.

\section{ELECTRICITY REFORM HISTORY}

From the mid-1880s industrial concerns and local communities were early developers of electricity infrastructure in New Zealand. Funding and coordinating the large-scale development of hydroelectric power schemes quickly became a national priority, however, and bringing together geographically separate generation and demand through a nationwide transmission grid resulted in central government ownership and control of generation and transmission. Local body ownership and control of distribution and energy retailing remained for much of the twentieth century in the form of 61

Figure 1. Schematic of the New Zealand electricity system (adapted from Ministry of Economic Development (2003))

Electricity Supply Authorities (ESAs) having monopoly service rights and obligations in local franchise areas.

As of 1984 the responsibility for generation and transmission lay with the Electricity Division of the Ministry of Energy, with control of these sectors ultimately centralized under a government minister. Wholesale electricity prices were set and announced by the minister at the annual ESA industry conference, and while they were intended to recover system running and maintenance (but not capital) costs, they were influenced by political imperatives such as controlling price inflation. Erratic price changes, distorted price signals to electricity consumers, and mis-timed generation investments resulted.

In 1985 the Secretary to the Treasury reported on New Zealand's experience with centralized generation planning and production costs (Galvin (1985)). Prevailing arrangements had failed to deliver electricity at least practicable cost - the objective of the day. Over-investment arose due to systematic and gross overestimates of demand growth, and investment projects suffered from commissioning delays, large cost over-runs 
and electricity production costs well in excess of those predicted. Given the significant share of the nation's assets represented by generation and transmission, it is therefore unsurprising that the new 1984 government soon set its sights on electricity reform.

The first major electricity reform initiative was to transfer the generation and transmission operations of the Ministry to a newly-created, profit-driven State-Owned Enterprise (SOE). Electricity Corporation of New Zealand (ECNZ), was thus established on 1 April 1987 under the SOE Act 1986, while at the same time the state's statutory monopoly on generation was removed. Transmission was ringfenced as a subsidiary of ECNZ, Transpower New Zealand, in 1988, albeit transmission and wholesale energy charges remained bundled until 1993.

The SOE Act model contained inherent tensions. While it created a degree of operational autonomy for state-owned commercial activities, political incentives for ministers to involve themselves in sensitive decisions (such as electricity price changes) and to impose non-commercial objectives remained. The model's proponents regarded it as a transitional measure pending privatization, and that delays in putting such companies beyond political reach would inevitably result in an erosion of SOEs' autonomy and primarilycommercial focus.

In 1989 a government-established task force recommended the separation of generation and transmission, the privatization of ENCZ (without break-up), and corporatisation and privatization of distribution/retailing. Transpower was formally established as a stand-alone SOE in 1994, and government continued to examine the potential for generation to be broken up despite ECNZ objections.

The first major test of these initiatives came in the form of a show-down over electricity pricing in 1991 (see Martin (1998)). Following four years of real wholesale electricity price reductions and falls in excess capacity, ECNZ announced its intention to raise prices to signal the cost of (and to fund) required new generation investment. The Corporation faced both ESA revolt and direct government opposition to the move, and rather than see its independence directly compromised by political direction, it adopted a price rise lower than announced.

Added to this show-down was a political retreat from the general policy of privatizations, meaning ECNZ faced increasing risk of being returned to a government department model of governance and control. To avoid such retrenchment it sought to foster greater competition in generation (a political hedge against break-up), and key to this was the development of a WEM to replace the centralized annual haggling between ECNZ and the ESAs, and also to distance electricity prices from political influence.

With government support an industry study group comprising ECNZ, Transpower, the ESAs and four major electricity users was formed to examine the need for a WEM. In 1992 it recommended the development of a facilitated electricity market comprising an independent grid, wholesale pool and contract market. This was in preference to pro-competitive regulation, traditional regulation (e.g. supply obligations and price- or returnregulation) and public supply. A government-sponsored follow-up study in 1994 echoed those recommendations with a voluntary wholesale market, and Transpower providing non-discrminatory grid access - but also sought constraints on ECNZ's generation dominance. Meanwhile ECNZ, Transpower, the ESAs and consumer groups sponsored the creation of a joint venture company (M-Co) to design and implement a WEM, later called the NZEM, ${ }^{1}$ and in 1994 also agreed arrangements for bilateral energy trading (MARIA). ${ }^{2}$

The culmination of these initiatives was the establishment of a trial secondary market for ECNZ hedge contracts in 1994, and a fully-operational voluntary and industry self-governing WEM in October 1996. Full operations coincided with the spin-out of $28 \%$ of ECNZ's generation capacity into a new SOE (privatized in 1999), Contact Energy, that was to compete with ECNZ. At the same time government confirmed its reliance on competition (as opposed to regulation or

\footnotetext{
New Zealand Electricity Market. Metering and Reconciliation Information Agreement.
} 
other intervention) to achieve efficiencies and consumer benefits in electricity, gas and telecommunications services. ECNZ was subsequently separated into a further three competing generators - Meridian Energy, Genesis Energy and Mighty River Power - in 1999. Also in 1999 industry introduced self-governance arrangements for determining grid security standards (MACQS), ${ }^{3}$ formerly the purview of Transpower.

Throughout this period reforms also progressed at the retailing and distribution level, first with corporatisaton in 1993 to set such activities on a commercial footing, and also with the phased abolition of supply obligations and franchise monopolies concluding in 1994. Mergers and efficiency gains soon followed, but major reform in the sector came with the government-imposed ownership separation of distribution from competitive activities such as generation and retailing in 1999. With restrictions on vertical integration by generators into retailing lifted at the same time, the newly-formed competing generators quickly acquired retail

\section{MORE RECENT REFORMS}

Until 1999 central government direction of the industry continued to a degree, but generally involving decentralization of industry control to state-owned yet semiautonomous bodies. Industry-led initiatives - notably the creation of the voluntary and self-governing NZEM - were both a reflection of, and attempt to enhance and secure, industry's growing capacity for selfdetermination and responsibility for meeting government's overall industry objectives.

This transition was not without its tensions. The imposed separation of distribution from other competitive activities under 1998 legislation was a significant example of political impatience with a perceived slowness in the development of retail-level competition. Transpower found itself unable to implement pricing policy changes in the face of distribution company

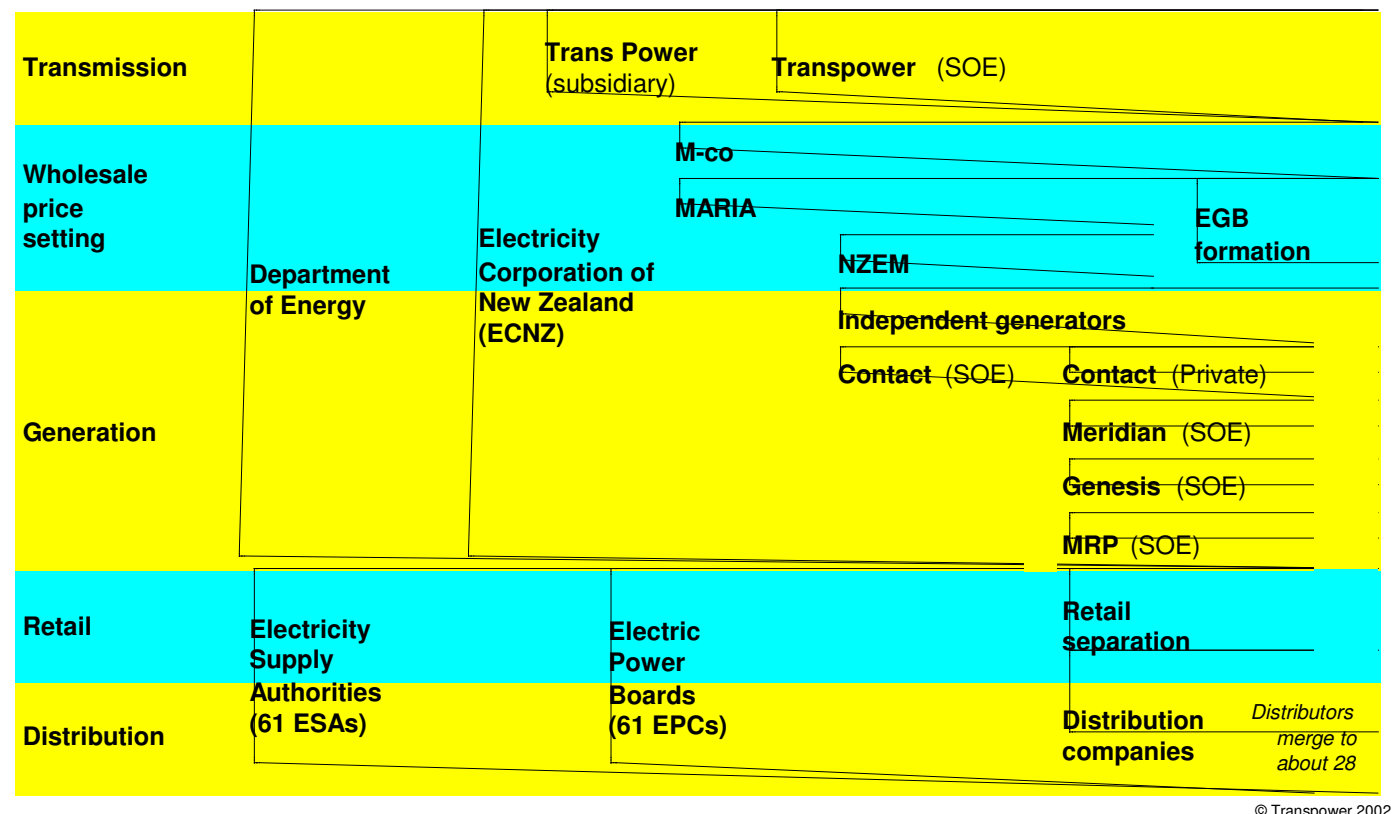

Figure 2. Electricity Retorm Timeline (courtesy of Transpower) operations to form "gentailers".

Until March of 2004 these arrangements largely persisted, with the history of electricity sector reforms illustrated in Figure 2.

\footnotetext{
$3 \quad$ Multilateral Agreement on Common
} Quality Standards. 
opposition, and faced difficulties in maintaining and developing the grid. And the self-governing and industry-created NZEM soon found itself being asked by government to include a government policy statement in its governing rules. Yet industry generally responded to any government requirements for change, and its newfound autonomy (however imperfect) was not overtly under threat.

With a change of government in late 1999, however, it was possible to discern echoes of the changes quickly implemented by its 1984 predecessor, albeit in the reverse direction. In June 2000 an inquiry into the electricity industry reported on whether whether existing regulatory arrangements met the government's objective of ensuring that "electricity is delivered in an efficient, reliable and environmentally sustainable manner." Without establishing its case, the inquiry recommended that industry's selfregulating governance arrangements NZEM, MARIA and MACQS - ought to be consolidated under a single self-governing body (an Electricity Governance Board, $E G B$, later the $E C$ ) independent of industry, and with that body's reach being extended to cover transmission and distribution pricing. It further recommended a departure from the previous 13 years of "light-handed" regulation in favour of incentive (i.e. CPI-X) regulation.

Industry was invited to consolidate its industry governance arrangements as recommended, under threat of imposed changes should industry agreement not be forthcoming. In the event agreement could not be reached, notably with state-owned Transpower favouring an imposed regulatory alternative to the EGB. Consequently industry governance was reined in under a new regulatory body, the EC - once again under the control of a government minister - from 1 March 2004.

Adding impetus to the 2000 inquiry recommendations was a winter power supply crisis in 2001 (and supply scare in 2003) which government interpreted as a sign of industry and market failure. Winter electricity shortages due to volatile hydro inflows and limited hydro storage were not uncommon prior to the reforms, and remain a risk even with recent government moves to contract for reserve "dry-year" generation capacity. Prior to the reforms, however, such shortages inevitably involved enforced blackouts, whereas since the reforms they have instead been reflected in soaring wholesale electricity prices (from which retail prices have remained largely insulated) and voluntary savings campaigns. Whether or not these winter shortages could be blamed on industry rather than hydrology remains moot, particularly since post-reform environmental laws constrain new generation investments that might relieve shortages whereas pre-reform investments in over-capacity did not avert shortages and enjoyed both statutory endorsement and taxpayer subsidy. However, government took the recent shortages to be added justification for reversing the electricity governance reforms of the preceding 15 years.

\section{ONGOING SUPPLY SECURITY AND INVESTMENT ISSUES}

Accompanying the creation of the EC is a raft of new regulation-making powers as well as fundamental shifts in industry control. The NZEM has been subsumed by the EC. Transmission pricing and investment has passed from centralized determination by semi-autonomous Transpower to centralized determination by the EC under the ultimate control of a government minister (leaving Transpower as grid owner and system operator). Even competitive electricity retail prices (i.e. not just monopoly transmission or distribution prices) have now been regulated. And while current legislative amendments will reduce the extent to which the EC is beholden to its minister, it will remain less autonomous than other regulatory bodies (e.g. the Commerce Commission) and is soon to receive considerably greater regulatory scope. Notable among its forthcoming powers will be an ability to regulate significant operational discretions of both state- and privately-owned generators, such as hydro spill, fuel reserves and levels of supply contracting.

Such moves beg the question as to whether a return to the centralized control model of before the reforms will better ensure low electricity prices and limit supply shortages (or better manage their 
impact)? Certainly government has made itself squarely responsible for future industry performance and any failings. This was all-too-apparent when a risk of transmission outages in parts of the South Island materialised in the winter of 2004. Since transmission capacity has been the responsibility of centralized and stateowned Transpower throughout the reform period it cannot be said that such risks are a reflection of market failure (although it has been suggested that a loss of coordination between centralized generation and centralized transmission is to blame). While both Transpower and the EC denied responsibility for the outage risk, it was clear that the responsible minister was now squarely accountable for the outcome.

While the recent centralization of industry control under government has the potential to overcome any coordination problems hampering efficient new investment in generation and transmission, it is neither necessary (as the PJM experience in the US would suggest) ${ }^{4}$ nor without its own pitfalls. Post-reform environmental laws continue to constrain investment in both areas, and the EC does not resolve this. Besides, other challenges remain with new ones also arising.

An infrastructure audit commissioned by government (PricewaterhouseCoopers (2004)) reported that the key issue facing generation is whether investment will be sufficient to meet the country's ongoing electricity needs. Among other things, it prominently identifies the impact of the EC, and particularly the uncertainties now created by its wide-ranging regulatory powers and how they may or may not be applied, as a key factor in stalling solutions to supply security issues. And this despite the EC being charged with securing electricity supply. Additionally, generators are delaying investment pending resolution of transmission pricing issues and allocation methodologies for new transmission investment costs. Unsurprisingly these issues remained unresolved while industry faced years of governance uncertainty created initially by

\footnotetext{
$4 \quad$ Electrical interconnection area encompassing Delaware, Maryland, New Jersey, Ohio, Pennsylvania, Virginia, West Virginia and the District of Columbia
}

the June 2000 inquiry recommendations and then by the subsequent centralization of industry governance under the new EC. Since the EC is yet to resolve these issues such key uncertainties must remain, which will materially undermine its supply security responsibilities. The new solution is now a key part of the problem.

While uncertainties regarding the EC's operations and effect might be expected to subside with time, two more fundamental uncertainties now confront long-term investments in generation and transmission. The first stems from the return to explicit politicisation of electricity governance. Since industry governance now ultimately resides with a government minister, industry governance can now change with a change of government. This creates a material increase in investment risk for private investors seeking to invest in New Zealand, as future investment returns are more exposed to adverse policy shifts.

The more fundamental uncertainty now confronting electricity investment in New Zealand, however, is reform uncertainty. Since the mid-1980s industry reform progressed in the main towards greater reliance on market solutions and a steady level of decentralized industry governance. Recent reforms reverse this trend and raise the spectre of future reform aboutturns - in either direction - within the lifetime of new long-lived investments. Since investors will respond to the incentives politicians place before them, it should be expected that future electricity investments will now be determined less on their economic benefits and more on the ability of their sponsors to manage nowincreased political risks. To the extent investors are unable to adequately manage those risks they will simply defer or suspend new investment and/or seek better or more certain returns in other jurisdictions. Once again the New Zealand taxpayer may find itself the only party willing and able to underwrite new electricity investment in New Zealand while other countries continue to successfully encourage private investors to provide the necessary capital and bear the long-tailed risks.

\section{DISCUSSION AND CONCLUSION}


New Zealand's electricity reforms are not remarkable for having commenced against a backdrop of centralized government ownership and control of generation and transmission. Nor is it remarkable for now having instituted a centralized government agency responsible for regulating industry's performance and progress. They are, however, remarkable in at least three respects.

First is that New Zealand's early decentralization of industry governance albeit incomplete and always contingent on satisfactory industry evolution - was sufficient to spur very significant industryled reforms. The creation of a voluntary, self-governing centralized WEM remains a significant and distinctive achievement. So too are the MARIA and MACQS agreements which, together with the NZEM, constituted industry selfgovernance until their assumption by the new EC. They are testament to the ability of industry to constructively respond to government's desired reform objectives, even if its perceived slowness and unavoidable exposure to climate-driven winter supply shortages ultimately provided government the justification it needed to reassert control of the process.

Second is the fact that the newly centralized industry governance now arises with greater private investment in the sector, but only a fraction of that now enjoyed in other reforming jurisdictions. New Zealand now has an electricity sector that is both regulated and predominantly either government- (generation, retailing and transmission) or locally-owned (distribution). To the extent that government or local ownership provides a natural hedge against monopoly abuses by grid or lines operators, or market power abuses by oligopolistic generators, the addition of heavy-handed regulation is arguably disproportionate. Certainly the recently-introduced $\mathrm{CPI}-\mathrm{X}$ regulation of transmission and distribution, and now price regulation of retailing, affects the incentives for new investments in each of these sectors. With the possible introduction of operational-level and other regulations by the new EC this is only more so. It also arises in the absence of the significant sales proceeds on offer from privatisation - which proceeds other reforming jurisdictions have secured without sacrificing consumer gains, employment or investment.

Finally, New Zealand's more recent reforms are notable for their inconsistency with ongoing reforms in other jurisdictions. As mentioned above, while the fact of a reformed but regulated sector is unremarkable, it is remarkable that New Zealand's response to real or perceived industry failings has been to revert to essentially the same centralized governance model as that existing at the beginning of the process. Electricity reform has shown itself to be an incremental process, with earlier mistakes or mis-steps subsequently remedied. However, subsequent reform measures have typically built on earlier moves towards private sector involvement and increased use of decentralized market mechanisms. The introduction of NETA ${ }^{5}$ in England and Wales is a notable example. New Zealand, for its part, appears to be abandoning reliance on decentralized market solutions in favour of a more centralized administrative model. In so doing, and given the deferral of needed investments in the sector in the face of increased investment risks associated with the new $E C$, it risks replacing evolutionary re-reform with counter-productive "de-reform".

\section{REFERENCES}

1. Arnold, T. and Evans, L.: Governance in the New Zealand Electricity Market: A Law and Economics Perspective on Enforcing Obligations in a Market Based on a Multilateral Contract, The Antitrust Bulletin, Fall 2001.

2. Electricity Corporation of New Zealand: Electricity Pricing in New Zealand, October 1991.

3. Electricity Shortage Review Committee: The Electricity Shortage 1992.

4. Evans, L., Grimes, A., Wilkinson, B., Teece, D.: Economic Reform in New Zealand 1984-95: The Pursuit of Efficiency. Journal of Economic Literature, Vol. XXXIV, December 1996, pp. 1856-1902.

5. Galvin, B.: Review of Electricity

5 New Electricity Trading Arrangements 
Planning and Electricity Generation Costs. The Treasury.

6. IEA: Energy Prices and Taxes, various.

7. Martin, J.: People, Politics and Power Stations: Electricity Generation in New Zealand 1880 - 1998, 2 ed., 1998.

8. Ministry of Economic Development: Energy Data Files. July 2003. www.med.govt.nz.

9. Ministry of Economic Development: Inquiry into the Electricity Industry, June 2000.

10.New Zealand Electricity Commission. www.electricitycommission.govt.nz.

11. New Zealand Electricity Market: Responding to Challenges. Market Report for January-December 2001, March 2002.

12. New Zealand Electricity Market: $A$ Foundation for New Zealand's Evolving Electricity Market. Market Report for January-December 2003, February 2004.

13. PricewaterhouseCoopers: Electricity Line Business 2003 Information Disclosure Compendium, November 2003.

14. PricewaterhouseCoopers: Infrastructure Stocktake: Infrastructure Audit, January 2004.

15.Transpower New Zealand Limited. www.transpower.co.nz.

\section{Richard Meade}

was born in 1968 in Wellington, New Zealand. $\mathrm{He}$ received bachelors degrees in economics and finance (BCA) and statistics and operations research (BSc) from Victoria University of Wellington, where he also received a Bachelor of Science degree with first class honours (BSc (Hons)) in those subjects. His career began in investment banking, and now he is principal of Cognitus Advisory Services Limited, proividing commercial and economic advice. Richard is a Research Associate with the New Zealand Institute for the Study of Competition and Regulation Inc, and also lectures in corporate finance and governance at Victoria University of Wellington. He is a member of the New Zealand Insitute of Directors and Law \& Economics Association of New Zealand. His areas of interest include corporate finance, microeconomic analysis, and corporate governance.

Mailing address:

Richard Meade

Cognitus Advisory Services Limited

10 Mairangi Road, Wadestown, Wellington

\section{NEW ZEALAND}

Phone: (+64) (4) 499-1031.

Fax: (+64) (4) 499-1033.

e-mail: richard.meade@cognitus.co.nz 